\section{Climate may not be linked with circulation slowdown}

SIR - Your News Feature "A sea change" (Nature 439, 256-260; 2006) states that evidence for the huge effects on climate of past thermohaline shutdowns is "near indisputable". You then daim that the best such evidence is the coincidence of thermohaline slowdown with the flooding of the North Atlantic following the collapse of Lake Agassiz, about 12,000 years ago at the beginning of the Younger Dryas cold period.

Yet Wallace Broecker, one of the chief proponents of the relationship between thermohaline circulation changes and climate, finds otherwise. In a recent study (T. V. Lowell et al. Eos 86, 365-373; 2005), Broecker and colleagues suggest that the case for the coincidence of these events is quite weak, and might well be wrong. Instead, they say, "preliminary findings imply a retreating ice sheet margin approximately 1000 years younger than previously thought, which would have blocked key meltwater corridors at the start of the Younger Dryas".

Of course, the proximal cause of a thermohaline "shutdown" (if such a thing can happen) is a separate issue from the influence of such a shutdown on dimate. But it is highly relevant to this discussion of the sensitivity of the thermohaline circulation to current and future climate forcing.

\section{Eric Steig}

Department of Earth and Space Sciences, University of Washington, Box 351310, Seattle, Washington 98195, USA

\section{No unfairness in funding of Croatian minister's project}

SIR - Your News story “Croatian scientists call for openness over funding " (Nature 439, $7 ; 2006$ ) brings attention to the funding of technology-development projects in Croatia. The petition discussed in this story was signed by only 26 scientists inside Croatia (the other signatories are foreign or students), and in my view it is frivolous.

The funding application made by Krešimir Pavelić of the Rudjer Bošković Institute, as senior investigator, and Dragan Primorac, who was then at Holy Spirit II Hospital, was among 28 applications received for this 'nucleus' programme. After an independent review including international experts, eight applications were recommended for funding The technology council that reviewed the Pavelić-Primorac application was appointed by Gvozden Flego, the minister in the previous government. Primorac was the most junior of the 13 members of the council; as is customary and appropriate, he excused himself when his application was considered.
The recommendation for funding was forwarded to Flego and was approved before Primorac became a member of the new government. Primorac did not affect the decision about the funding of his own project. He stepped down from the project when Pavelić assumed the full directorship of it, and before any funds were released to the Rudjer Bošković Institute.

The technology council dosely monitors the execution of projects and requires quarterly reports from project directors. This mechanism assures that the funds are spent in accordance with the project's mandate and in compliance with the highest financial and ethical standards. In addition, the directors must present a public defence at the conclusion of their projects.

Stjepan Risović

Technology Council, Ministry of Science, Education and Sports, Trg Josipa Jurja Strossmayera 4, 10000 Zagreb, Republic of Croatia

\section{Dwindling fish numbers already of concern in 1883}

SIR - Jennifer Devine and colleagues in their Brief Communication "Deep-sea fishes qualify as endangered" (Nature 439,$29 ; 2006$ ) state: "At one time it was presumed from the vastness of the oceans that fishing would not drive species to extinction." Indeed, the UK Royal Commission on the Sea Fisheries in 1866, whose officers included Thomas Henry Huxley, reported that fears of overexploitation were unfounded. The commission recommended that existing laws regulating fishing grounds and closed seasons should be removed. But the rise in fish trade and reports about the scarcity of fish from all around the United Kingdom's coasts strengthened widespread concern among fishing communities and in scientific circles.

It all came to a head in 1883 at the International Fisheries Exhibition in London, a conference called to discuss commercial and scientific aspects of the fishing industry. In his inaugural address Huxley repeated the views of the royal commission by discounting reports of dedines in fish catches. "With existing methods of fishing, he said, "it is inconceivable that the great sea fisheries, such as those for cod, herring and mackerel, could ever be exhausted."

Fortunately, there were some present who ventured to disagree. Their views were put forward by Edwin Ray Lankester.

"It is a mistake to suppose that the place of fish removed on a particular fishing ground is immediately taken by some grand total of fish, which are so numerous in comparison with man's depredations as to make his operations in this respect insignificant," said Lankester. "If man removes a large proportion of these fish from the areas which they inhabit, the natural balance is upset."

Huxley and the royal commission did not foresee the advances in technology that accelerated depletion, particularly the move from sail to steam and then motor trawling. Even as late as 1919 there were influential British scientists, such as W. C. McIntosh, who denied that the sea's bounty could be exhausted by human activity (Nature 103, $355-358$ and 376-378; 1919, and Walter Garstang's response, Nature 104, 48-49; 1919). But the earlier actions of their opponents ultimately stimulated the formation of several UK marine laboratories, such as those at Plymouth, Lowestoft and Millport, that conduct fish biology and fishery investigations to this day.

It is sobering to note that the concerns and problems facing people some 120 years ago are in some ways similar to those of scientists, industry and administrators today. Now, however, worldwide marine-fish populations are declining at an unprecented rate, requiring greater international cooperation, research capacity and timely action.

David W. Sims, Alan J.Southward

Marine Biological Association of the UK, The Laboratory, Citadel Hill,

Plymouth PL1 2PB, UK

\section{Problems at plutonium lab need more than a quick fix}

SIR — In addition to the concerns expressed in your Editorial "Enough, already" (Nature 438,$712 ; 2005$ ), about the planned increase in plutonium stored at Lawrence Livermore National Laboratory (LLNL), numerous other problems exist which do not lend themselves to ready fixes. LLNL is very near two earthquake faults, one of which - the Greenville fault — produced a 5.5-magnitude quake in 1980, causing extensive damage to lab buildings and opening a 120 -metre discontinuous crack on the site.

LLNL is also a designated Superfund Site, identified by the Environmental Protection Agency for contaminants to be cleaned up. Local parks, gardens and yards have been shown to contain varied, sometimes unknown, levels of plutonium as the result of contaminated sewage sludge, according to a report by the California Department of Health Services in November 2002.

Tritium is also found on many sites in the Livermore valley: local wines contain concentrations of it well above background levels. During the past few years, these concentrations have decreased, but it is feared that the increase in use of tritium in the National Ignition Facility and other lab operations will reverse the trend.

Martha Priebat

3375 Norton Way 2, Pleasanton,

California 94566, USA 